\title{
Implementation of E-Government Policy in Making Smart Governance at Government Communication and Informatics Department, Bandung
}

\author{
Implementasi Kebijakan E-Government dalam Mewujudkan \\ Smart Governance pada Dinas Komunikasi dan Informatika \\ Pemerintahan Kota Bandung
}

\author{
Budi Nugraha \\ Program Magister Ilmu Administrasi Fakultas Pascasarjana, Universitas Pasundan \\ Email: budinugraha965@gmail.com
}

\begin{abstract}
This research is based on the main problem of E-Government in realizing Smart Governance in Bandung. The implementation of E-Government Policy has not been maximized in realizing Smart Governance in the Office of Communication and Information Technology of the City Government of Bandung. The opinion in this study is related to policy implementation seen from the context of public policy and public administration as the main theory for developing public administration knowledge. With the SWOT analysis, this study shows that first, the environmental conditions in the Bandung Information and Communication Office are good, but E-Government management in creating Smart Governance in the implementation stage is still weak in terms of supervision. Second, inadequate facilities for the implementation of E-Government. Third, the relationship pattern between work units and prevailing norms needs to be improved in its implementation. The fourth implementation of E-Government policies in realizing Smart Governance has been running, but has not touched all aspects of achieving success.
\end{abstract}

Keywords: policy implementation, e-government management

\begin{abstract}
ABSTRAK
Penelitian ini didasarkan pada masalah pokok E-Government dalam mewujudkan Smart Governance di Kota Bandung. Belum maksimalnya Implementasi Kebijakan E-Government dalam mewujudkan Smart Governance pada Dinas Komunikasi dan Informatika Pemerintahan Kota Bandung. Pendektan dalam penelitian ini terkait dengan implementasi kebijakan dilihat dari konteks kebijakan publik dan administrasi publik sebagai teori induknya untuk mengembangkan khazanah ilmu administrasi publik. Dengan Analisis SWOT penelitian ini menunjukkan bahwa pertama, kondisi lingkungan di Dinas Komunikasi dan Informatika Kota Bandung sudah baik, tetapi pengelolaan E-Government dalam menciptakan Smart Governance dalam tahap pelaksaan masih lemah dari segi pengawasan. Kedua, sarana belum memadai untuk implementasi EGovernment. Ketiga, pola hubungan antarunit kerja dan norma-norma yang berlaku perlu ditingkatkan dalam pelaksaannya. Keempat implementasi kebijakan E-Government dalam mewujudkan Smart Governance sudah berjalan, tetapi belum menyentuh seluruh aspek pencapaian keberhasilan.
\end{abstract}

Kata Kunci: Implementasi Kebijakan, Pengelolaan E-Government 


\section{INTRODUCTION}

Policy implementation is a very important stage in the policy structure. Through this procedure an overall policy process can influence the level of success or failure of achieving the objectives. For example the implementation of policies regarding smart cities as described by Vice President Jusuf Kalla (2014-2019) who launched the 2015 Indonesia Smart City Index (IKCI) program at the Jakarta Convention Center on March 24, 2015. This program is one way to improve the performance of government administration area.

Local government through innovation in Law no. 23 of 2014 concerning Regional Government, in Chapter XXI entitled Regional Innovation. From Article 386 to Article 390 of Law $23 / 2014$, it is explained that in order to improve the performance of the regional administration, Regional Governments can make innovations. The innovation referred to is all forms of reform in the administration of Regional Government. In formulating the implementation of the smart city policy in Bandung of innovation policy, local government refers to the principle of: increasing efficiency; effectiveness improvement; service quality improvement; no conflicts of interest; oriented to the public interest; done openly; meet the values of propriety; and the results can be accounted for, not for one's own sake.

The development of media and technology nowadays Bandung as a city with higher growth requires a more capable urban system. For this reason, in this digital era, the city government needs to upgrade the supervisory capabilities of the city government. With real-time city surveillance, it can solve problems effectively and efficiently. In dealing with this, the city government is developing a supervisory concept with the Bandung Smart City, where all offices in the city government of Bandung are well monitored.

Smart city is defined as a city development and management concept by using Information and Communication Technology (ICT) to connect, monitor, and control various resources in the city more effectively and efficiently to maximize services to its citizens and support sustainable development.

The dimensions of the smart city concept according to Grifflinger et al., (2007:10-14) explain the 6 dimensions in the smart city concept as the basis for implementing smart city which is then used in calculating the smart city index for 70 cities in Europe, the six dimensions of which are as follows: 1) Smart Economy, 2) Smart People, 3) Smart Governance, 4) Smart Mobility, 5) Smart Environment, 6) Smart Living

In this study, we focus on the dimensions of smart governance, which sees the suitability of developing the city of Bandung into a smart city in terms of governance dimensions. The efforts made by the city government of Bandung with the concept of smart governance in realizing Bandung Smart City include: 1) Installing 5000 wifi points in every public space (http://www.sinarpaginews.com accessed on Monday, 10 October 2016 at 22:31). 2) Panic Button application for Bandung residents to follow up on criminal acts (https://kominfo.go.id accessed on Monday 3 October 2016 at 22:34). 3) The Government of Bandung launched the Aspiration Service program and (https://portal.bandung.go.id/launching-lapordiakses on Monday 3 October 2016 at 22.51). 4) Public services through social media networks such as twitter by all SKPDs of Bandung (https://portal.bandung.go.id/koneksi/social-mediadiaccessed on Monday 3 October 2016 at 22.59). 5) Built the Bandung Command Center as the control center for the city of Bandung. (http://www.bumn.go.id/inti/berita accessed on Monday 3 October 2016 at 23.02). 6.) Development of Bandung Technopolis which will be the prototype for the implementation of Smart City in Indonesia (http://jabar.tribunnews.com/2015 /03/05/technopolis accessed on Monday 3 October 2016 at 23.04).

Source: City of Bandung Information and Communication Office, 2016.

To make the city of Bandung as a city labeled as smart city is not easy, so that in implementing the smart city policy there are still many problems faced by the city of Bandung government as seen in the following figure: 


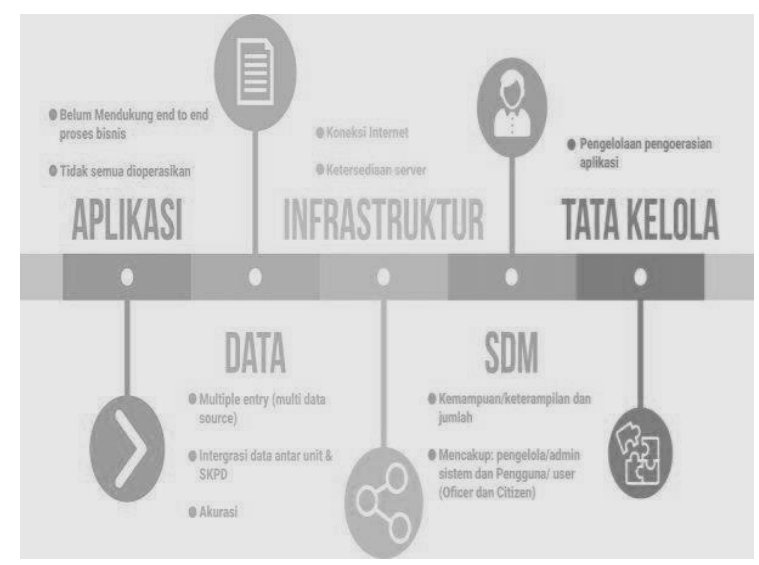

Figure 1: Smart City Problems

Source: Data from the City of Bandung Information and Communication Office, 2016.

From the observations, the researcher found several problem phenomena. Researchers take four dimensions in looking at the problem phenomenon to measure the successful implementation of the smart city policy in the city of Bandung, including: environmental conditions, the relationship between resource organizations and the characteristics of the ability of implementing agents.

The first problem is related to environmental conditions, population growth in the city of Bandung continues to increase from year to year, both from natural growth and population migration from other areas. In addition, changes in the characteristics of the city of Bandung from agricultural to urban characteristics or what is commonly called an area with an urbanization process, on the other hand, land resources are limited and fixed, so that population growth cannot be accompanied by land availability which will lead to population density, giving birth to slum dwellers, domestic and household waste, congestion and other environmental problems. If this continues, it will certainly lead to an unhealthy city, so it needs efforts to solve it.

In the dimension of organizational relations, there are several problems encountered. The main problem is the reluctance of regional work units to share data to the service. The presumption is that if information and communication office wants to process data and integrate data, then please information and communication office to find its own data. This shows the lack of commitment of regional work units in implementing smart government. Several other problems related to the implementation of smart city, especially in the dimension of smart government, are suspected to also occur a lot in its application.

The communication aspect, namely the socialization carried out by the city of Bandung government has not been evenly distributed in every region and the policy has not been fully implemented by the regencies/cities. Even though the socialization of smart city has been carried out by the city of Bandung government, one of which is by holding a smart city forum which was held at the Ballroom of the Trans Luxury Hotel Bandung, Friday, September 2, 2016 by Mr. Ridwan Kamil as the Mayor of Bandung at that time. The Smart City Forum was attended by 38 regional heads and representatives from 76 regencies / cities throughout Indonesia.

The next problem concerns human resources and non-human resources (infrastructure). Implementing a policy implementing policies must know and understand what must be done in implementing a policy. However, in practice, not all of them understand the policies made, so the city government of Bandung holds a special education and training program to explore the smart city program for employees, especially employees in the communication and informatics office because this service is the implementer.

The non-human resources of the city government of Bandung are currently trying to solve this problem by improving network infrastructure through the construction of ducting, namely the reduction of electric cables through pipes into the underground and making MCF 
(microcellful), which is used for distributing Hand Phone signals. The construction of a duct was carried out to maintain the security and comfort of the community in accessing services and to beautify the aesthetics of the city layout to make it look neat.

In addition, the socialization that has not been evenly distributed in every region is caused by people who are not technologically literate. There are still many people who do not know technology and even rarely access the internet or other media so that information is not conveyed. Even though various efforts have been made by the Bandung government to socialize the application of smart city in the community, namely through various media such as print, online, radio, TV.

The next problem regarding human resources is an important aspect in achieving the implementation of a smart city, but the fact is that the placement of employees in government is not according to their skills. Only in the placement stage of reliable human resources in the field of technology (IT) so that for the improvement and smoothness of the smart city program, the city of Bandung government recruits out sourching personnel, especially in the IT field. This recruitment is very strict, out of a thousand registrants, only 5 people are accepted because they are reliable employees in the IT field. Employees who are experts in the IT field are very important in supporting the implementation of a smart city as conveyed by the Head of Telematics Infrastructure Facilities and the Head of the General Subdivision at the City of Bandung Government Information and Communication Service.

Disposition or attitude of policy implementers, If a policy implementer wants to be effective, then policy implementers must know and have the ability to implement it. However, until now there are still some things that are difficult to change, especially those related to behavior. One example is bureaucratic behavior. For example, in terms of licensing, there are still many city government officials who are working too slowly. Thus, the mayor must personally go into the field for the inspection.

Bureaucratic behaviour is very influential in building a smart city, so that the implementation of the smart city program makes it an efficient city for the community, a city that is fit to live in, public services occur well, the level of the economy is high, and the level of city infrastructure is organized and neat. For this reason, the city government of Bandung wants to make it all happen by building smart people to support smart city. However, to make smart people is not easy so that the mayor of Bandung first builds a smart government because the government is the implementor of the smart city. Based on the description of the phenomenon that begins with the research background that leads to the research problem, the researcher will examine in more depth the research focus on unsuccessful implementation of public policies.

\section{RESEARCH METHODS}

This research uses a qualitative approach. The qualitative method was chosen as 'naturalinguiry' (the context is natural, not artificial), or Interpretiveinguiry (because it involves many subjective factors of informants and research subjects), relevant to the case studied (Irawan, 2006: 5). The data needed in this research is primary data that is sourced or obtained from informants through field research on the implementation of e-government policies in realizing smart cities and secondary data is obtained through literature searches, documentation, and activity reports contained in various related work units. The secondary data required is the scope of financial data, the scope of data for e-government management in realizing a smart city in the City of Bandung Government Information and Communication Agency.

Informants who act as sources of data and information must meet the requirements, the key informants in this study are officials/ officials of the City of Bandung Government Information and Communication Agency. All of these informants are employees at the Office of Communication and Information Technology of the City Government of Bandung and the Informants, namely, the head of the City Government of Bandung Information and Communication Office (1 person); Head of Division (1 person) General Information and Communication Agency of the City Government of Bandung; head of Section (1 person), 
represented by the General Section; City of Bandung Government Regional Work Unit (3 people); and Head of Buah Batu and Camat Kiara Condong (2 people).

Data collected from the subject through the results of in-depth interviews in the field, interview transcripts were made by changing the results of the interviews from recorded to verbatim written form. Then, the transcript data were coded, grouped by theme categories and response patterns, then arranged in an analysis framework that was made or prepared. After the categories of data patterns are clearly defined, the researcher examines the data against the assumptions developed in this study, so that it can be matched whether there are similarities between the theoretical basis and the results achieved. Although this study does not have a specific hypothesis, from the theoretical basis assumptions can be made about the relationship between existing concepts. In addition, data reduction is carried out as a process of selecting, clarifying, abstracting or transparency of data obtained in the field through observation and interviews with informants. After that, the presentation of data and drawing conclusions.

\section{RESULT AND DISCUSSION \\ Implementation of E-Government Policy in creating Smart Governance at the City of Bandung Information and Communication Office.}

\section{Environmental Conditions}

The environmental conditions at the City of Bandung Information and Communication Office are good. This is evidenced from the opinion of the informants that there are social, cultural, and program recipient conditions in E-Government Management in creating Smart Governance. The City of Bandung Information and Communication Office and the officials in it are always trying through activities in managing E-Government funds. The social system implemented by the Health Service Agency is already running and the work culture can be followed by the Dinas apparatus. However, if there are deficiencies, it needs to be improved.

\section{Relationships between organizations}

From the results of interviews with informants, it can be concluded that the dimensions of the relationship between organizations for the Implementation of PMK 248/2010 Policy on EGovernment Management in creating Smart Governance at the City of Bandung Information and Communication Office have been running according to the provisions.

The cooperation relationship between the Health Office and other related agencies in EGovernment Management in creating Smart Governance has been going well with Bandung Information and Communication Office or other agencies. Although there is a pattern of cooperation related to E-Government Management in creating Smart Governance, the implementation stage is still weak in terms of supervision. To overcome this, the Bandung Information and Communication Office communicates intensely in making better cooperation in E-Government Management in creating this Smart Governance.

\section{Resources}

From the results of interviews with informants, it can be concluded that the dimensions of resources for E-Government management in creating Smart Governance at the Bandung Information and Communication Office, it can be concluded that the Bandung Information and Communication Office already understands the management of Deconcentration funds. The facilities and inscriptions already exist, but they are still not maximally supported in the management of the deconcentration fund. In addition, the sanctions that have been in effect have been running but still need to improve the apparatus being more aware of their work responsibilities.

Characteristics and Capabilities of the Implementing Agent

It can be concluded that the characteristics and capabilities of implementing agents for policy implementation, especially in E-Government Management in creating Smart Governance in the Office of Communication and Information Technology in Bandung are good and available. 
Although there are several things that need to be improved to support the implementation of EGovernment funding policies to make it even better. Among the patterns of relations between work units and prevailing norms must be further improved in its implementation. So that every given responsibility and task can be carried out properly. So that E-Government Management in creating Smart Governance can be carried out effectively and efficiently in accordance with applicable regulations and avoid problems, especially the problem of corruption.

\section{E-Government Policy Implementation Strategy in creating Smart Governance at the Bandung Information and Communication Office.}

The strategy begins by identifying strengths and weaknesses as internal factors and opportunities and threats as external facilitators that can influence the implementation of EGovernment policies in creating Smart Governance. The identification is as follows:

\section{Internal Environmental Analysis}

Strengths: 1) The strength of the city of Bandung has competent Human Resources (HR) in accordance with their respective fields; 2) There are 350 applications that support Bandung Smart City. Among them are accommodating public complaints, managing, providing information about Bandung, regarding reports on problems of Bandung residents, providing work effectiveness, paperless up to $80 \%$, the existence of the Bandung Command Center as the Bandung Smart City information technology control center which can also be used as an educational tourism destination, and is capable of reduce the Bandung budget by 1 trillion.

Weakness: 2) Inadequate socialization to the public regarding technological facilities from applications that support the needs of Bandung residents and the absence of a special portal, there is no definite maintenance from Vendors to Government; 2) Not all people are able to keep up with developments regarding technology.

\section{External Environmental Analysis}

Opportunities: 1) City of Bandung, which is an inspiration for other regions that want to also be areas that have a smart concept, the local government is able to manage existing data and information quickly so that it can provide good development in building the city; 2) Enabling people to become entrepreneurs so that they can improve the economy, such as the existence of jasmine credit, this system is designed to provide loan funds to the public to become entrepreneurs.

Threats: 1) From a political point of view there are some parties who still disagree with the existence of a smart city that is already in operation, it is difficult to apply the same concept in the related Bandung Smart City during the government term; 2) The existence of threats from the local community related to the existence of existing community facilities, and the mindset of the people that sometimes can still be influenced makes it difficult to unify the concept that a smart city needs a smart community too.

The two strategic environmental factors that result in the identification of some of the strengths, weaknesses, opportunities and threats mentioned above must be a collaborative strategy analysis. There are four main strategies that can be used to determine a strategy, namely $\mathrm{S}-\mathrm{O}$, which is a strategy that uses strength to achieve or seize opportunities. $\mathrm{W}-\mathrm{O}$ strategy, which is a strategy to suppress weaknesses to achieve or seize opportunities, $\mathrm{S}-\mathrm{T}$ strategy, a strategy that uses strength to face challenges or threats and W - T strategy, which is a strategy to suppress weaknesses to face challenges or threats. 
SWOT Analysis Cross Matrix

Table 1

Strategy Analysis Results

\begin{tabular}{|c|c|c|}
\hline & Strength & Weakness \\
\hline Opportunity & $\begin{array}{l}\text { Strategy: namely the } \\
\text { existence of qualified } \\
\text { Human Resources (HR) } \\
\text { who can maintain an } \\
\text { integrated product or } \\
\text { application which can } \\
\text { then be developed, thus } \\
\text { the need for } \\
\text { socialization. }\end{array}$ & $\begin{array}{l}\text { Collaboration: namely between } \\
\text { vendors and government related } \\
\text { to the development of } \\
\text { applications that support and } \\
\text { create a special portal for } \\
\text { Bandung Smart City. }\end{array}$ \\
\hline Threat & $\begin{array}{l}\text { Innovation or focus: } \\
\text { namely on policies } \\
\text { regarding the making of } \\
\text { local regulations to } \\
\text { continue to develop } \\
\text { Bandung Smart City. }\end{array}$ & $\begin{array}{l}\text { Turn around or Exit: that is, by } \\
\text { developing technology from } \\
\text { previous applications or creating } \\
\text { applications with new, smarter } \\
\text { technologies, which also have } \\
\text { good security. }\end{array}$ \\
\hline
\end{tabular}

Source: Researcher, 2019

Determination of Strategy Based on the Results of the Cross Matrix

Analysis of Internal Strategic Factors

Table 2

IFAS E-Government Management in creating Smart Governance Communication and Information Office of Bandung

\begin{tabular}{|c|c|c|c|c|}
\hline NO & Internal Strategy Factors & Score & Weight & $\begin{array}{c}\text { Score } \\
\text { (Weight X } \\
\text { Rating) } \\
\end{array}$ \\
\hline \multirow[t]{4}{*}{1} & Strengths & & & \\
\hline & Competent Human Resources (HR) & 4 & 0.5 & 3 \\
\hline & $\begin{array}{l}\text { There are } 350 \text { applications that support } \\
\text { Bandung Smart City }\end{array}$ & 2 & 0.1 & 0.2 \\
\hline & Total Strength & & 0.6 & 2.2 \\
\hline \multirow[t]{5}{*}{2} & Threats & & & \\
\hline & Lack of socialization to the community & -2 & 0.15 & -0.3 \\
\hline & $\begin{array}{l}\text { Not all people are able to keep up with } \\
\text { developments regarding technology }\end{array}$ & -2 & 0.25 & -0.5 \\
\hline & Number of Weaknesses & & 0.4 & -0.8 \\
\hline & Tota IFAS & & 1.00 & 1.40 \\
\hline
\end{tabular}

Source: Processed by researchers, 2019.

Strenght Posture $=\mathrm{S}+\mathrm{W}$

$=2.2+(-0.8)$

$=1.40$ 
Analysis of External Strategy Factors

Table 3

EFAS E-Government Management in creating the Smart Governance of the City of Bandung Information and Communication Office

\begin{tabular}{|c|c|c|c|c|}
\hline NO & Internal Strategy Factors & Score & Weight & $\begin{array}{c}\text { Score } \\
\text { (Weight X } \\
\text { Rating) } \\
\end{array}$ \\
\hline \multirow[t]{4}{*}{1} & Opportunities & & & \\
\hline & $\begin{array}{l}\text { The city of Bandung where the } \\
\text { inspiration for other regions }\end{array}$ & 3 & 0.35 & 1.05 \\
\hline & $\begin{array}{l}\text { Enabling people to become } \\
\text { entrepreneurs so that they can } \\
\text { improve the economy }\end{array}$ & 2 & 0.25 & 0.5 \\
\hline & Total Strength & & 0.6 & 1.55 \\
\hline \multirow[t]{5}{*}{2} & Threats & & & \\
\hline & $\begin{array}{l}\text { It is difficult to apply the same } \\
\text { concept in Bandung Smart City }\end{array}$ & -2 & 0.25 & -0.5 \\
\hline & $\begin{array}{l}\text { There is a threat from the local } \\
\text { community related to the } \\
\text { existence of community facilities } \\
\text { that are already running }\end{array}$ & -2 & 0.15 & -0.3 \\
\hline & Number of Weaknesses & & 0.4 & -0.8 \\
\hline & Total IFAS & & 1.00 & 0.75 \\
\hline
\end{tabular}

Position of the Bandung Information and Communication Office in the SWOT Quadrant

After the score for each aspect of the score, the score is placed as an ordinate point to describe the largest position area. Ordinate point to describe the largest position area:

$$
\begin{aligned}
& \text { SO }=(2.2: 1.55) \\
& \text { WO }=(-0.8: 1.55) \\
& \text { WT }=(-0.8 ;-0.8) \\
& \text { ST }=(2.2:-0.8)
\end{aligned}
$$

Ordinate point to describe the position of the organization in the quadrant and in the widest position from the SWOT aspect
(Strength Posture: 0)
$=(1.40: 0)$
( 0 :Competitive Posture)
$=(0: 0.75)$
(Strength Posture:Competitive Posture)
$=(1.40: 0.75)$ 


\section{Picture 1 \\ Organizational Position in the SWOT Quadrant}

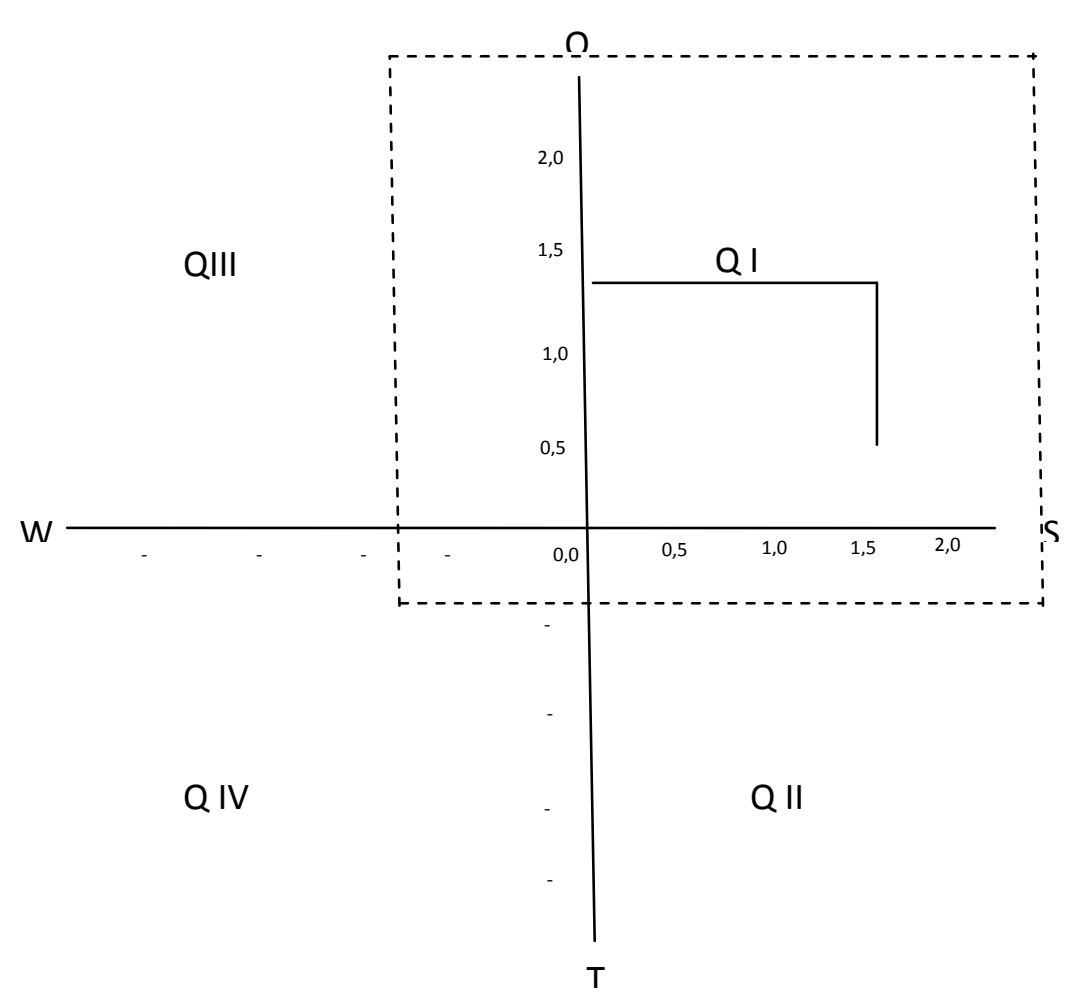

From the picture above, it can be seen that the suitable strategy used by the Bandung Information and Communication Office in managing E-Government is in quadrant I. This position indicates Quadrant I (positive, positive). This position signifies a strong and likely organization. The strategic recommendation given is Progressive, meaning that the Bandung Information and Communication Agency is in prime and steady condition so that it is possible to continue to expand, and achieve maximum management success.

A suitable strategy in order to achieve goals and objectives at the Bandung Information and Communication Office based on a SWOT analysis is a strategy that uses strength to achieve or seize opportunities ( $\mathrm{S}-\mathrm{O}$ ), including: a) Take advantage and improve human resources in managing e-government funds; and b) Give employees clear duties to manage e-government funds;

\section{CONCLUSION}

The general conclusion of this research shows that the implementation of e-government policies in creating Smart Governance in the Office of the Communication and Information Technology Office of Bandung is good, but there are still shortcomings. This can be seen from the findings obtained by researchers through observations and interviews, including:

First, the condition of the environment in the Bandung Information and Communication Office is already good. It is proven by the opinion of the informants that there are social, cultural conditions, and program recipients in the effort to manage e-government in creating smart governance.

Second, related to e-government management in creating smart governance, but in the implementation stage it is still weak in terms of supervision. The pattern of e-government management in creating smart governance is still uneven, there are differences between one agency and another.

Third, from the results of the interview, it can be concluded that the dimensions of resources for e-government management in creating smart governance at the Bandung Information and Communication Office have not been maximally for e-government management. 
Fourth, it can be concluded that the characteristics and capabilities of implementing agencies for implementing policies, especially in e-government management, in creating smart governance in the Bandung Information and Communication Office are already good. Although the pattern of relations between work units and prevailing norms must be further improved in its implementation.

\section{REFERENCES}

Giffinger, R. et al. (2007). Smart Cities: Ranking of European Medium-Sized Cities. Vienna, http://Www.Smartcities.Eu/Download/Smart_Cities_Final_Report.Pdf Found On 18th Of June, 2008.

Irawan, Prasetya. (2006). Penelitian Kualitatif dan Kuantitatif Untuk Ilmu-Ilmu Sosial. Depok: Fisip UI.

Kominfo. (2016). https://kominfo.go.id accessed on Monday 3 October 2016 at 22:34.

Law No. 23 of 2014 CHAPTER XXI Articles 386-390 About Local Government Innovation.

PMK 248 Tahun 2010 about E-Government Management in creating Smart Governance.

Portal Bandung. (2006). (https://portal.bandung.go.id/launching-lapor accessed on Monday 3 October 2016 at 22.51 .

Sinarpaginews. (2016). http://www.sinarpaginews.com accessed on Monday, October 102016 at $22: 31$.

Tribun Jabar. (2015). http://jabar.tribunnews.com/2015/03/05/technopolis accessed on Monday 3 October 2016 at 23.04. 